\title{
EVALUATION OF THE VEPTR SYSTEM IN THE MANAGEMENT OF SPINAL DEFORMITIES BETWEEN 2008 AND 2014 AT THE ROOSEVELT INSTITUTE
}

\author{
AVALIAÇÃO DO SISTEMA VEPTR NO TRATAMENTO DAS DEFORMIDADES ESPINAIS ENTRE \\ 2008 E 2014 NO INSTITUTO ROOSEVELT
}

\section{EVALUACIÓN DEL SISTEMA VEPTR EN EL MANEJO DE DEFORMIDADES ESPINALES ENTRE 2008 A 2014, EN EL INSTITUTO ROOSEVELT}

Carlos Segundo Montero ${ }^{1}$, David Meneses ${ }^{1}$, Fernando Alvarado ${ }^{1}$, Wilmer Godor ${ }^{1}$, Maria Margarita Acosta ${ }^{1,2,3}$, Ricardo José Méndez

\author{
1. Instituto Roosevelt, Spinal Surgery, Bogotá, Colombia \\ 2. Pontificia Universidad Javeriana, Bogotá, Colombia. \\ 3. Hospital San Ignacio, Bogotá, Colombia.
}

\begin{abstract}
Objective: Traditional surgical treatments, such as on-site fusion and hemiepiphysiodesis, have not addressed chest deformity in its three dimensions, and are usually insufficient and unpredictable for the management of congenital and neuromuscular scoliosis. The application of the Vertical Expandable Prosthetic Titanium Rib (VEPTR) is a technique developed to treat early-onset progressive scoliosis that elongates the spine and thoracic wall, allowing adequate lung development. Methods: A case series retrospective study was conducted. We included 23 patients, including fifteen females and eight males diagnosed with congenital and neuromuscular scoliosis, who were treated with VEPTR type implants between January 2008 and May 2014. We obtained data about the implant and pre and postoperative radiographic images to assess the magnitude of the curve, and we measured the Cobb angle and length after lengthening, as well as evaluating the complications found. Results: There was an improvement in the postoperative Cobb angle. In patients with congenital scoliosis, deformity correction was $8.6 \%(p=0.014)$, and in neuromuscular scoliosis, we observed deformity correction of 19.5\% ( $p=0.009)$. Likewise, we found gains in thoracic height through the device, which results in an average $10 \%$ lengthening of the spine in congenital scoliosis. In this study, we identified complications such as material migrations, rib synostosis, pressure zones, rib fracture, hemothorax, and deep wound infection. Conclusion: The natural history of progressive spinal deformity was improved in most of the minors, through the use of VEPTR. This allows us to continue managing patients in the future, in order to make a deeper assessment of its performance in treatment of early onset scoliosis. Level of Evidence III; Therapeutic studies - Investigating the results of a treatment.
\end{abstract}

Keywords: Scoliosis; Prostheses and implants; Child; Spinal curvatures.

\section{RESUMO}

Objetivo: Os tratamentos cirúrgicos tradicionais, como a fusão no local e o hemiepifisiodese, não abordam a deformidade torácica em suas três dimensões e, em geral, revelam-se insuficientes e imprevisíveis para o tratamento da escoliose congênita e neuromuscular. A aplicação de Rib Vertical de Titânio Protético Expansível (VEPTR) é uma técnica desenvolvida para tratar a escoliose progressiva de início precoce, que alonga a parede da coluna e do tórax, permitindo um desenvolvimento pulmonar adequado. Métodos: Foi realizado um estudo retrospectivo de série de casos. Foram incluídos 23 pacientes, incluindo quinze mulheres e oito homens diagnosticados com escoliose congênita e neuromuscular, que foram tratados com implantes do tipo VEPTR entre janeiro de 2008 e maio de 2014 . Foram obtidos dados sobre o implante; imagens radiográficas pré e pós-operatórias para avaliar a magnitude da curva e medimos o ângulo de Cobb e o comprimento após o alongamento, assim como avaliamos as complicações encontradas. Resultados: Melhora no ângulo pós-operatório de Cobb. Nos pacientes com escoliose congênita, a correção da deformidade foi de 8,6\% ( $p=0,014)$, e na escoliose neuromuscular observamos uma correção da deformidade de 19,5\% ( $p=0,009)$. Da mesma forma, encontramos ganhos na altura torácica através do dispositivo, o que resulta em uma média de $10 \%$ de alongamento da coluna vertebral na escoliose congênita. Neste estudo, identificamos complicações como migração de material, sinostose de costelas, zonas de pressão, fratura de costela, hemotórax e infecção profunda da ferida. Conclusão: A história natural da deformidade da coluna vertebral progressiva melhorou na maioria dos menores, através do uso de VEPTR. Isso nos permite continuar administrando pacientes no futuro, a fim de fazer uma avaliação mais profunda de seu desempenho no tratamento da escoliose de início precoce. Nível de evidência III; Estudos terapêuticos - Investigação dos resultados do tratamento.

Descritores: Escoliose; Próteses e implantes; Criança; Curvaturas da coluna vertebral.

\section{RESUMEN}

Objetivo: Los tratamientos quirúrgicos tradicionales, como la fusión in situ y la hemiepifisiodesis no abordan la deformidad torácica en sus tres dimensiones y, en general, resultan insuficientes e impredecibles para el tratamiento de la escoliosis congénita y neuromuscular. El uso del sistema VEPTR (prótesis vertical expansible de titanio) es una técnica desarrollada para tratar la escoliosis progresiva de inicio temprano alargando la pared de la columna y del tórax, que permite el desarrollo pulmonar adecuado. Métodos: Se realizó un estudio retrospectivo de serie de casos. Se incluyeron 23 pacientes, quince mujeres y ocho hombres con diagnóstico de escoliosis congénita y neuromuscular, 
tratados con implante tipo VEPTR entre enero de 2008 y mayo de 2014. Se obtuvieron datos sobre el implante e imágenes radiográficas pre y posoperatorias para evaluar la magnitud de la curva, y se midieron el ángulo de Cobb y la longitud luego del alargamiento, así como evaluamos complicaciones encontradas. Resultados: Se demostró mejoría en el ángulo de Cobb postoperatorio. En los pacientes con escoliosis congénita, la corrección de la deformidad fue del 8,6\% $(p=0,014)$ y en la escoliosis neuromuscular, observamos corrección del $19,5 \%$ ( $p=0,009)$. De la misma forma, encontramos aumentos en la altura torácica con el dispositivo, lo que resulta en un alargamiento promedio del 10\% de la columna vertebral en escoliosis congénita. En este estudio, identificamos complicaciones como migración de material, sinostosis de costillas, zonas de presión, fractura de costillas, hemotórax e infección profunda de la herida. Conclusión: La historia natural de la deformidad progresiva de la columna vertebral mejoró en la mayoría de los niños con el uso del VEPTR. Esto nos permite seguir tratando pacientes en el futuro, a fin de hacer una evaluación más profunda de su desempeño en el tratamiento de la escoliosis de inicio temprano. Nivel de evidencia III; Estudios terapéuticos - Investigación de los resultados del tratamiento.

Descriptores: Escoliosis; Prótesis e implantes; Niño; Curvaturas de la columna vertebral.

\section{INTRODUCTION}

There are multiple methods for the management of congenital and neuromuscular scoliosis in underage patients. ${ }^{1}$ Traditional surgical treatments, such as on-site fusion and hemiepiphysiodesis, have not addressed chest deformity in its three dimensions, and are usually insufficient and unpredictable; likewise, arthrodesis hinders the axial growth of the thoracic spine and proper lung development.

That is why, for several years, thanks to Campbell, ${ }^{2}$ expansion thoracoplasty with the application of VEPTR (Vertical Expandable Prosthetic Titanium Rib) has been in use. This technique directly treats thoracic insufficiency syndrome, and the related vertebral anomalies. ${ }^{2,3}$ The purpose of this management is to lengthening the constrained thorax wall to provide more space for the developing lungs, allow secondary thoracic growth, and prevent the progression of the scoliotic deformity. ${ }^{4-6}$

Based on the effective results of the VEPTR, ${ }^{8}$ we have designed a series of cases to investigate the clinical and radiological outcomes of the VEPTR system in the management of spinal deformities in patients at the Instituto de Ortopedia Infantil Roosevelt.

\section{METHODS}

The research protocol for this study was approved by our ethics committee and the institutional review board. All authors declare no potential conflict of interest related to this article. It is a case series type retrospective study including 23 patients with congenital or neuromuscular scoliosis with VEPTR implantation between January 2008 and May 2014. Fifteen females and eight males were included. The average age for initial insertion of the VEPTR was 5.9 years (range from 8 months to 12 years).

We collected specific data on implant construction, such as implant type and length; we also assessed complications, including infection, material failure, pressure zones, hemothorax, and synostosis. Preoperative and postoperative radiographs were analyzed by a spine specialist orthopedic surgeon, and a specialist in training. Radiological studies consisted of an AP and panoramic projection of the spine, and the magnitude of the curve was measured using the Cobb method. The total system length in the coronal plane was also measured, prior to VEPTR insertion and after each lengthening.

\section{Statistical analysis}

For the quantitative variables, we calculated the central tendency and dispersion measures (standard deviation SD); for the categorical variables, we calculated the proportions. Statistical differences were assessed using the T-student parametric test for related samples, as the variables showed normal distribution.

Analysis were carried out using IBM SPSS Statistics ${ }^{\circledR}$, version 21 statistical software.

\section{RESULTS}

During the period analyzed, 23 VEPTR implantation procedures were performed that met the selection criteria. $65 \%$ of the patients were females, with a mean age of 5.9 years ( \pm 3.2 SD). 86.6\% $(n=19)$ had been diagnosed with congenital scoliosis, and $17.4 \%$ $(n=4)$ with neuromuscular scoliosis. A total of 78 system lengthening surgeries were performed, with an average of $3.4( \pm 1.7 \mathrm{SD})$ lengthenings per patient and follow-ups every 29 months (6 to 63 months), on average. The study parameters are shown in Table 1.

In regards to the surgical procedure, we found that the mean surgical time for system placement was $188 \pm 54.8$ minutes, and for the lengthening procedures, $105 \pm 36.5$ minutes. Intraoperative bleeding during the system placement and lengthening procedures was $208.5 \pm 201.89 \mathrm{~mL}$ and $53.05 \pm 65.22 \mathrm{~mL}$ respectively.

The average preoperative Cobb angle was $58.14^{\circ} \pm 20.02^{\circ}$, and the post-lengthening Cobb angle was $50.96^{\circ} \pm 14.57$, with an average correction of $7.18^{\circ}$, which is statistically significant $(p=0.003)$. It should be noted that we did not perform the preoperative Cobb angle measurement for two patients, as they received extra-institutional management.

We identified two complications during the first surgical time: a rib fracture and a surgery site infection that required lavage and debridement in the operating room. Complications during the lengthening procedures included anchoring failure after lengthening (this was surgically corrected during the following lengthening), a costal synostosis, a costoscapular synostosis, a sacral pressure zone, a hemothorax, and a deep infection. There were two patients that experienced device migrations which were corrected in the following lengthening. One patient required multiple lavages and debridements due to a device-related deep infection.

We carried out an analysis in subgroups, depending on the type of scoliosis, to assess the results in patients who received the VEPTR system (Table 2).

Nineteen patients with congenital scoliosis were treated with this system. Some showed and associated Dysmorphic syndrome, horseshoe kidney, Noonan syndrome, VACTERL association, Klippel-Feil syndrome, Moebius syndrome, and myelomeningocele, among others. This group includes the two patients for whom we did not have the preoperative Cobb angle data. We assessed the VEPTR management of neuromuscular scoliosis in 4 patients with the following backgrounds: one with bilateral cerebral paralysis, two with myelomeningocele, and one with VACTERL association.

On average, patients diagnosed with congenital scoliosis were followed-up for 33 months (9-63 months), while patients with neuromuscular scoliosis were followed-up for 12 months (5-30 months).

Due to the simple size and the heterogeneity of the groups, no comparisons were made between groups. However, we assessed the magnitude of the scoliosis correction for each group, considering the Cobb angle and spine length during the pre- and postoperative periods (Figures 1 and 2).

For patients with congenital scoliosis, the average preoperative Cobb angle was $51.12^{\circ} \pm 13.74$ degrees, and the mean postoperative Cobb angle was $46.70^{\circ} \pm 11.83$ degrees, demonstrating a reduction in the magnitude of the deformity of $8.6 \%$, which is statistically significant $(p=0.014)$; we also found significant lengthening of the spine, measured through the system, with a preoperative length of $183.80 \pm 53.90 \mathrm{~mm}$, and a postoperative length of $203.87 \pm 57.18 \mathrm{~mm}$, demonstrating a $10 \%(p=0.002)$ gain in spinal length. 
Table 1. Study parameters.

\begin{tabular}{|c|c|c|c|c|c|c|c|c|c|c|c|}
\hline \multirow{2}{*}{$\begin{array}{c}\begin{array}{c}\text { Patient } \\
\text { No. }\end{array} \\
1\end{array}$} & \multirow{2}{*}{\begin{tabular}{|c}
$\begin{array}{c}\text { Age } \\
\text { (years) }\end{array}$ \\
8 \\
\end{tabular}} & \multirow{2}{*}{$\begin{array}{c}\text { Sex } \\
\text { Female }\end{array}$} & \multirow{2}{*}{$\begin{array}{c}\begin{array}{c}\text { Type of } \\
\text { scoliosis }\end{array} \\
\text { Congenital }\end{array}$} & \multirow{2}{*}{$\begin{array}{l}\text { Associated diagnoses } \\
\text { Dysmorphic syndrome, } \\
\text { Klippel-Feil Syndrome }\end{array}$} & \multirow{2}{*}{\begin{tabular}{|c}
$\begin{array}{c}\text { Total } \\
\text { lengthenings }\end{array}$ \\
5 \\
\end{tabular}} & \multirow{2}{*}{$\begin{array}{c}\begin{array}{c}\text { Follow-up } \\
\text { (months) }\end{array} \\
58 \\
\end{array}$} & \multicolumn{2}{|c|}{$\begin{array}{l}\text { Pre/post } \\
\text { Op. Cobb } \\
\text { angle } \\
\text { (degrees) }\end{array}$} & \multicolumn{2}{|c|}{$\begin{array}{l}\text { Length Firsts/last } \\
\text { lengthening }(\mathrm{mm})\end{array}$} & \multirow{2}{*}{$\begin{array}{c}\text { Complications } \\
\text { None }\end{array}$} \\
\hline & & & & & & & * & 58 & 214.07 & 264.16 & \\
\hline 2 & 8 & Male & Congenital & Horseshoe kidney & 6 & 36 & 45 & 37 & 179.76 & 185.86 & None \\
\hline 3 & 8 & Male & Congenital & & 5 & 35 & * & 55 & 326.50 & 355.89 & None \\
\hline 4 & 1 & Female & Congenital & & 6 & 38 & 38 & 49 & & & None \\
\hline 7 & 8 & Male & Congenital & & 3 & 48 & 56 & 45 & 160.50 & 178.09 & Costal synostosis \\
\hline 8 & 8 & Male & Congenital & VACTERL association & 4 & 26 & 52 & 48 & 190.66 & 183.50 & None \\
\hline 9 & 9 & Female & Congenital & VACTERL association & 6 & 40 & 50 & 43 & 248.76 & 234.00 & None \\
\hline 10 & 2 & Female & Congenital & Myelomeningocele & 4 & 45 & 60 & 44 & 109.76 & 132.61 & Rib fusion \\
\hline 11 & 4 & Female & Congenital & Moebius syndrome & 2 & 18 & 28 & 25 & 198.29 & 203.16 & None \\
\hline 12 & 2 & Female & Congenital & Scapulo-thoracic synostosis & 2 & 20 & 60 & 62 & 183.48 & 201.05 & Scapula-rib union \\
\hline 13 & 3 & Female & Congenital & VACTERL association & 3 & 63 & 66 & 56 & 217.38 & 223.54 & Deep SSI \\
\hline 17 & 7 & Male & Congenital & & 3 & 27 & 33 & 17 & 169.81 & 176.63 & $\begin{array}{l}\text { 10th costal arch } \\
\text { fracture }\end{array}$ \\
\hline 18 & 3 & Female & Congenital & & 1 & 9 & 52 & 54 & 168.30 & & None \\
\hline 19 & 0.7 & Female & Congenital & $\begin{array}{c}\text { Myelomeningocele Arnold } \\
\text { Chiari }\end{array}$ & 3 & 23 & 24 & 34 & 87.55 & 109.92 & Hemothorax \\
\hline 20 & 7 & Female & Neuromuscular & $\begin{array}{c}\text { Thoracic and lumbar } \\
\text { myelomalacia }\end{array}$ & 1 & 6 & 68 & 58 & 214.00 & & Material loosening \\
\hline 21 & 5 & Female & Neuromuscular & Myelomeningocele & 1 & 5 & 89 & 71 & 222.06 & & None \\
\hline 22 & 11 & Female & Neuromuscular & Myelomeningocele & 4 & 30 & 99 & 82 & 228.60 & 269.94 & Material loosening \\
\hline 23 & 7 & Female & Neuromuscular & VACTERL association & 1 & 6 & 96 & 72 & 234.11 & & None \\
\hline
\end{tabular}

* There were no presurgical studies available, patients with extrainstitutional management.

Table 2. General characteristics of patients with VEPTR system by diagnosis

\begin{tabular}{c|c|c|c|c}
\hline Diagnostic & \multicolumn{2}{|c|}{$\begin{array}{c}\text { Congenital } \\
\text { scoliosis } \\
\text { (n= 19) }\end{array}$} & \multicolumn{2}{c}{$\begin{array}{c}\text { Neuromuscular } \\
\text { scoliosis (n=4) }\end{array}$} \\
\hline Sex, $\mathbf{n}$ (\%) & & & & \\
\hline Female & 11 & $57.9 \%$ & 4 & $100.0 \%$ \\
\hline Age (years), mean \pm SD & 5.6 & \pm 3.3 & 7.5 & \pm 2.5 \\
\hline Total Lengthenings(n= 78) & \multicolumn{5}{|l}{} \\
\hline Average lengthenings & 3.7 & \pm 1.6 & 1.8 & \pm 1.3 \\
\hline Time between lengthenings (months) & 9.3 & \pm 3.8 & 6.1 & \pm 1.0 \\
\hline Preop Cobb angle (degrees) & 51.12 & \pm 13.74 & 88.00 & \pm 13.97 \\
\hline Post-op Cobb angle (degrees) & 46.70 & \pm 11.83 & 70.81 & \pm 9.94 \\
\hline System placement time (minutes) & 192 & \pm 56.8 & 165 & \pm 32.4 \\
\hline System lengthening time (minutes) & 97 & \pm 21.7 & 141 & \pm 61 \\
\hline System placement bleeding (mL) & 231.2 & \pm 210.3 & 80.0 & \pm 65.5 \\
\hline System lengthening bleeding (mL) & 40.8 & \pm 37.1 & 45.0 & \pm 31.2 \\
\hline SD: Standard Deviation. & & & \multicolumn{2}{l}{}
\end{tabular}

In patients with neuromuscular scoliosis, the preoperative Cobb angle was $88.00 \pm 13.97$ degrees, and the mean postoperative Cobb angle was $70.81 \pm 9.94$ degrees, demonstrating a statistically significant $19.5 \%(p=0.009)$ reduction in the magnitude of the deformity. Comparison between the pre- and postoperative spine angles was possible, due to the available sample size.

\section{DISCUSSION}

Pathologies affecting the spine during early childhood include Scoliosis, which may be of the idiopathic, congenital, or neuromuscular types.

In the past, patients with early-onset scoliosis were managed with body casts; later on, the use of fixations and short arthrodesis, including hemiepiphysiodesis, were the treatment of choice, but these resulted in a short chest with severe breathing restrictions, due to the notable reduction in chest capacity. ${ }^{9}$

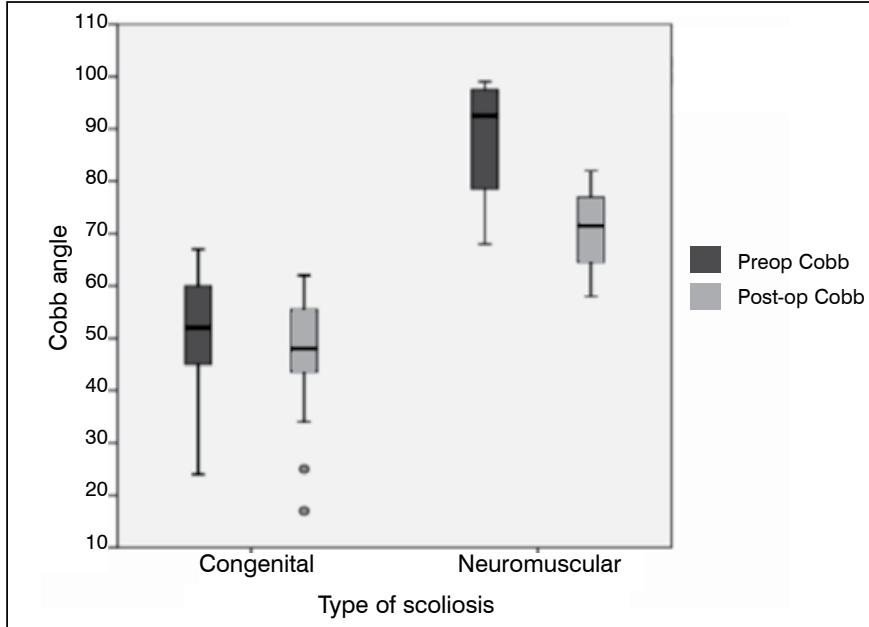

Congenital scoliosis: Preoperative VEPTR system length $183.80 \pm 53.90 \mathrm{~mm}$ (mean \pm SD) postoperative $203.87 \pm 57.18 \mathrm{~mm}(\mathrm{p}=0.002)$; Neuromuscular scoliosis: Preoperative VEPTR system length $224.69 \pm 8.66 \mathrm{~mm}$ (mean $\pm \mathrm{SD})$

Figure 1. Correction magnitude (degrees) by patient diagnosis.

The current concept of this pathology has dramatically changed with the appearance of spinal distraction systems, including growth rods such as costal distraction systems, including the VEPTR progressive lengthening system; ${ }^{10}$ the purposes of this system are to allow proper growth of the rib cage and the compromised hemithorax, and to control the deformity of the spine, allowing its growth. ${ }^{11}$

In order to better defining the indications and results of patients treated with VEPTR, we report here the data from mid-term followup. Data for this study were added to a database of the Instituto de ortopedia infantil Roosevelt, including data on specific preoperative and postoperative clinical and radiographic assessments. Based on this database, we identified 23 children with congenital 


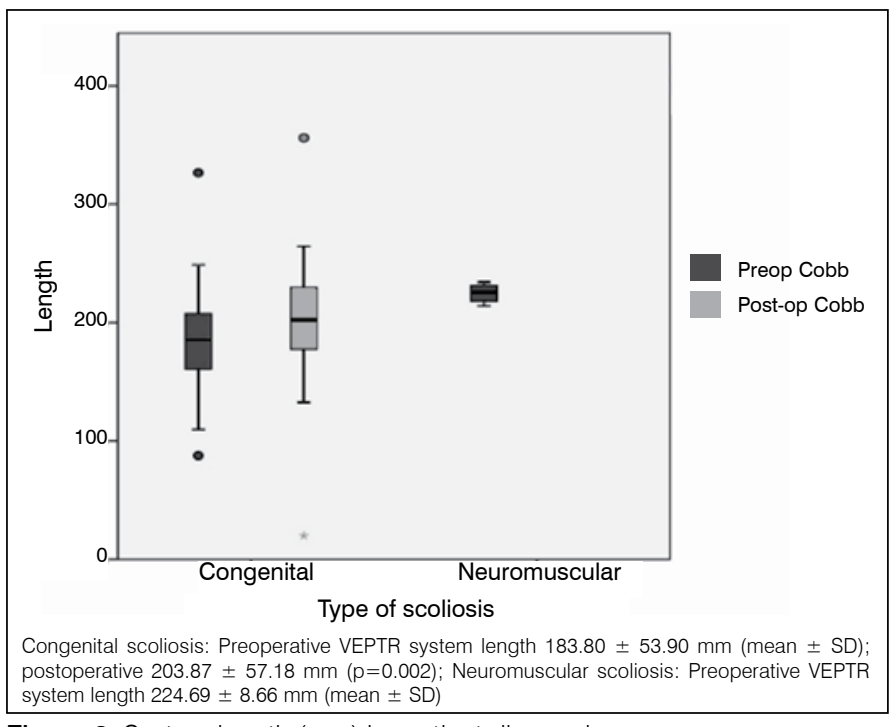

Figure 2. System length $(\mathrm{mm})$ by patient diagnosis.

and neuromuscular scoliosis. Much of the current literature on the use of VEPTR includes patients with associated syndromes, such as Jarcho-Levin syndrome, myelomeningolcele, VACTER, or progressive infantile scoliosis.

Since the advent of VEPTR for chest expansion, by broadening the available space for optimum lung development, an improvement has been seen in bone deformities of the spine. Therefore, this system is now used to address early onset scoliosis. This treatment is indicated in children who still have lung growth potential.

In our study, we had 23 patients with spinal deformities, nineteen with congenital scoliosis and four with neuromuscular scoliosis. We found in our series that the majority of patients showed an improvement in the Cobb angle and a reduction in the magnitude of the deformity; in those with congenital scoliosis, the average correction was $8.6 \%(p=0.014)$, and in those with neuromuscular scoliosis, we observed a mean reduction of $19.5 \%(p=0.009)$. The highest rate of Cobb angle correction occurred in neuromuscular scoliosis patients. Likewise, we saw a gain in chest height measured through the VEPTR in patients with congenital scoliosis, with spinal length increase of $10 \%(p<0.001)$.

Out of the total followed-up sample, we saw three patients who completed treatment with VEPTR, and who were then taken to final surgery with success. The remaining 21 patients are still growing, with favorable clinical and radiological progress.

Challenges of this treatment, as shown in prior studies, include the demand for multiple procedures, skin problems, and device migration. ${ }^{12,13}$ In this study, we identified two migrations of the material, one costal synostosis, one costoscapular synostosis, one sacral pressure zone, costal fracture, one patient with hemothorax, and one deep infection. Device migrations were surgically corrected in the next lengthening. One patient was submitted to multiple lavages and debridements due to a device related deep infection.

\section{CONCLUSIONS}

We presented a case series-type retrospective research study to assess the efficacy of VEPTR, and thoracotomy expansion in patients with multiple spine anomalies. As of the time of follow-up, the technique has proven successful for improving thorax height and spine deformity. The complication rate is similar to that of prior descriptions in other studies and in the use of other lengthening devices. Despite the small number of cases in our study, it reveals the efficacy of the system in our Institute and in Colombia, where no studies of this type are available. This allows us to continue managing patients in the future, in order to make a more in-depth assessment of its performance in treatment of early onset scoliosis.

All authors declare no potential conflict of interest related to this article.

CONTRIBUTION OF THE AUTHORS: Each author made significant individual contributions to this manuscript. CSM (0000-0001-9403-8947)* and FA (0000-0002-8854-0356)* were the main contributors in the drafting of the manuscript. All the authors reviewed the clinical charts to obtain data for the study. FA, MMA (0000-0003-0070-4799)*, and RJM evaluated the data from the statistical analysis. MMA and RJM performed the literature search and review of the manuscript, and contributed to the intellectual concept of the study. ${ }^{*}$ ORCID (Open Researcher and Contributor ID).

\section{REFERENCES}

1. Hell AK, Campbell RM, Hefti F. The vertical expandable prosthetic titanium rib implant for the treatment of thoracic insufficiency syndrome associated with congenital and neuromuscular scoliosis in young children. J Pediatr Orthop B. 2005:14(4):287-93.

2. Campbell RM Jr, Smith MD, Mayes TC, Mangos JA, Willey-Courand DB, Kose N, et al. The characteristics of thoracic insufficiency syndrome associated with fused ribs and congenital scoliosis. J Bone Joint Surg Am. 2003;85-A(3):399-408.

3. Campbell RM Jr, Smith MD. Thoracic insufficiency syndrome and exotic scoliosis. J Bone Joint Surg Am. 2007;89(Suppl 1):108-22.

4. Flynn JM, Emans JB, Smith JT, Betz RR, Deeney VF, Patel NM, et al. VEPTR to Trea Nonsyndromic Congenital Scoliosis: A Multicenter, Mid-term Follow-up Study. J Pediatr Orthop. 2013;33(7):679-84.

5. Campbell RM Jr, Hell-Vocke AK. Growth of the thoracic spine in congenital scoliosis after expansion thoracoplasty. J Bone Joint Surg Am. 2003:85-A(3):409-20.

6. Dimeglio A. Growth of the spine before age 5 years. J Pediatr Orthop B. 1992;1(2):102-7.

7. Latalski M, Fatyga M, Gregosiewicz A. The vertical expandable prosthetic titanium rib (VEPTR) in the treatment of scoliosis and thoracic deformities. Preliminary report. OrtopTraumatol Rehabil. 2007;9(5):459-66.

8. Emans JB, Caubet JF, Ordonez CL, Lee EY, Ciarlo M. The treatment of spine and chest wall deformities with fused ribs by expansion thoracostomy and insertion of vertical expandable prosthetic titanium rib. Spine (Phila Pa 1976). 2005; 30(17 Suppl):S58-68.

9. Smith JR, Samdani AF, Pahys J, Ranade A, Asghar J, Cahill P, et al. The role of bracing, casting, and vertical expandable prosthetic titanium rib for the treatment of infantile idiopathic scoliosis: a single-institution experience with 31 consecutive patients. Clinical article. J Neurosurg Spine. 2009;11(1):3-8.

10. Ramirez N, Flynn JM, Serrano JA, Carlo S, Cornier AS. The vertical expandable prosthetic titanium rib in the treatment of spinal deformity due to progressive early onset scoliosis. J Pediatr Orthop B. 2009;18(4):197-203.

11. Smith JT, Novais E. Treatment of Gibbus deformity associated with myelomeningocele in the young child with use of the vertical expandable prosthetic titanium rib (VEPTR): a case report. J Bone Joint Surg Am. 2010;92(12):2211-5.

12. Greggi T, Lolli F, Di Silvestre M, Martikos K, Vommaro F, Maredi E, et al. Complications incidence in the treatment of early onset scoliosis with growing spinal implants. Stud Health Technol Inform. 2012;176:334-7.

13. Latalski M, Fatyga M, Gregosiewicz A. Problems and complications in VEPTR-based treatment. OrtopTraumatol Rehabil. 2011;13(5):449-55. 